\title{
Governance Quality and Information Asymmetry
}

\author{
By Ahmed Elbadry, Dimitrios Gounopoulos, and Frank Skinner
}

\begin{abstract}
This paper explores the relation between corporate governance and asymmetric information. We find that proxies for governance mechanisms that encourage the monitoring of managers are inversely related to proxies for asymmetric information. Specifically, greater board independence, board activeness and debt financing are significantly and inversely related to the degree of asymmetric information as reflected in bid-ask spreads, volatility of share returns, normalised share trade volumes and market value of shares traded. This implies that corporate governance mechanisms that enhance managerial monitoring lead to improvements in the informational environment of the firm.
\end{abstract}

Keywords: Corporate Governance Mechanisms, Asymmetric Information, Agency Theory.

JEL Codes: G34, D82, G30, G32.

\section{INTRODUCTION}

In this study, we relate corporate governance mechanisms to measures of asymmetric information. Specifically, we used bid-ask spreads, share return volatility and share trading volume as proxies of asymmetric information. Shareholders are well aware that managers can impose agency problems through shirking and consuming excess perquisites (Jensen and Meckling (1976); Fama and Jensen (1983)) but unlike the managers, shareholders are uncertain as to the extent of these problems. This can lead to higher bid ask spreads, volatility and lower share trading volumes as this uncertainty can cause shareholders to be more cautious in buying shares than they would be in the absence of this information asymmetry.

Best practise in corporate governance can deal with the impact of this information asymmetry in several ways. For example, some elements of best practise in corporate governance such as an independent board of directors encourages the monitoring of managers thereby making it difficult for managers to conceal shirking and personal perquisite consumption. As another example, compensation schemes such as share compensation reward managers for reducing agency problems. To the extent that a corporation has in place the elements of best practice in corporate governance, shareholders can have greater confidence that agency problems are under control. In turn this greater confidence can lead to lower bid ask spreads, lower share return volatility and higher share trading volumes as shareholders are less cautious in acting on new information and trade in shares as they are less concerned about agency problems than they would have been in the absence of these corporate governance elements. Therefore we ask, does best practise in corporate governance enhance shareholder confidence that agency problems are under control thereby reducing the impact of asymmetric information and lead to an improvement in the market for the firm's shares? Additionally, 
what are the governance mechanisms that encourage the monitoring of managers and what is their relation with asymmetric information? Do these mechanisms lead to improvements informational environment?

Our study is motivated by the theoretical work of Diamond (1985) and Diamond and Verrecchia (1991), who emphasize the effects of asymmetric information among the management of the firm and the shareholders on the market for the firm's shares. A general implication of these theoretical models is that that stock-holder welfare can be improved in perfectly competitive and fully liquid markets by disclosing data that reduce information asymmetry among investors. While Diamond and Verrecchia (1991) use information disclosure as the means of reducing asymmetric information, their points are more general, if a firm reduces the impact of information asymmetry, it can also improve the liquidity of its shares and reduce its cost of capital. A recent empirical example of this is Armostrong et al. (2012) who suggest antitakeover laws as the means of reducing asymmetric information. Another example is Jiang et al. (2011) who demonstrate that voluntary disclosures significantly attenuate information asymmetry risk associated with ownership concentration.

Despite the voluminous literature on the general topic of corporate governance, there has been limited investigation of the relation between the nature of the firm's corporate governance system and the degree of asymmetric information and some of the little evidence that has been acquired is contradictory. For instance, Shleifer and Vishny (1997), Perotti and Thadden (2003), Pawlina and Renneboog (2005) and Florackis and Ozkan (2009) find that the presence of large shareholders are inversely related to asymmetric information and improve long-term performance. In contrast, Heflin and Shaw (2000) and O'Neill and Swisher (2003), Belghitar et al. (2011) find that greater institutional ownership is associated with greater information asymmetry, as there is a lower degree of informed trading. Meanwhile, studies that do examine the relation between corporate governance and asymmetric information usually deal with limited aspects, or individual mechanisms, of corporate governance. In contrast, we provide a more comprehensive view of the relation between corporate governance and asymmetric information by exploring the ability of eight proxies for aspects of corporate governance to explain five measures of asymmetric information all the while controlling for self-selection bias, and size and industry effects.

We explore five elements of corporate governance that can be used to control agency problems either by enhancing monitoring systems or by incentivizing managerial behaviour. The first and second elements are that the more independent and the more active the board of directors, the more effective the board can be in monitoring the shirking and perquisite consumption behaviour of managers. The third element is that compensation schemes that are designed to enhance performance also incentivize managers to reduce shirking and perquisite consumption. The fourth element is more complex. On the one hand, dominate shareholders can monitor management closely thereby discouraging shirking and excess perquisite consumption. On the other hand, dominate shareholders can encourage managers 
to act in their best interests rather than all shareholders. Therefore, like uncertainty in the level of agency problems, increases in ownership concentration can also increase uncertainty in the likelihood that managers can take actions to the detriment of the majority of shareholders leading to uncertainty in the value of shares, larger bid ask spreads, higher volatility and lower share trading volumes. The fifth element is that debt financing improves the monitoring of management, thereby making it more difficult for managers to conceal shirking and excess perquisite consumption.

We find that proxies related to board independence, board activity and debt financing are inversely related to the degree of asymmetric information, whereas ownership concentration and performance-related executive compensation schemes is not significantly related to the degree of asymmetric information. We control for self-selection, size and industry effects and conduct robustness checks based on a composite asymmetric information measure derived from a principal component analysis of four standard measures of asymmetric information, as well as the economic environment and calendar year. Our results are confirmed by the composite asymmetric information variable. Interestingly, our robustness checks for the economic environment finds that ownership concentration is directly related to the degree of asymmetric information and the significance of this result is concentrated during the height of the recent financial crisis. Moreover, board independence and debt financing are robust with respect to calendar year. In other words, we find that governance mechanisms that encourage board independence, greater board activity and debt financing, appear to improve the firm's informational environment through a more efficient market for the firm's shares. Overall, our results also suggest that the recommendations of the Combined Code on Corporate Governance (Financial Reporting Council 2010) regarding board independence and activity can play a role in controlling information asymmetry leading to enhanced confidence in the share price as manifest in lower bid ask spreads and volatility and higher trading volumes.

The remainder of our paper is organized as follows: The next section discusses the literature and the following section presents hypothesis concerning the five elements of corporate governance that we examine. Our fourth section explains the model and the sample selection. Our fifth section presents the results followed by a sixth section that reports our robustness checks. Finally, we present our conclusions.

\section{LITERATURE REVIEW}

According to agency theory, ${ }^{1}$ agency problems arise as a result of the divergence of interests among agents and principals (e.g., Jensen and Meckling, (1976);

\footnotetext{
${ }^{1}$ The literature has many models and theories related to the concept of asymmetric information. Kennedy et al. (2006) review asymmetric information models in a multi-period setting to explain under-pricing in IPOs. These models are signalling, information production, market feedback, entrepreneurial losses, changing objective function, and the information momentum models. Deshmukh
} 
Shleifer and Vishny, (1997); Miller (2002)). Principals cannot resolve agency problems because of asymmetric information concerning the efforts and actions of agents. Because the principals cannot perfectly monitor or measure the behaviour of agents, agency problems are unresolved. They are manifest when the agents (managers) impose additional direct costs on the firm such as consuming personal perquisites or by imposing opportunity costs such as shirking, and by imposing uncertainty in the value of the firm's shares since the existence but not the extent of these agency problems is known to the market (Jensen and Meckling, (1976); Fama and Jensen (1983)).

Corporate governance mechanisms are an indirect and probably imperfect tool by which shareholders, as principals, attempt to control agency problems by changing the behaviour of managers, who are the agents of the shareholders (Deshmukh (2005), Kanagaretnam, Lobo and Whalen (2007); Chen et al. (2007); Connelly et al. (2009)). Managers' actions can be changed by mitigating the effects of asymmetric information in many ways. For instance, a significant portion of managerial compensation can be tied to the share price via share price compensation thereby linking higher compensation to lower shirking and perquisite consumption. In addition, corporate governance mechanisms can discourage agency problems by increasing the effectiveness of monitoring systems, say by increasing the number of independent directors on the board. These measures inhibit collusion, and make it more difficult for managers to hide their perquisite consumption and shirking behaviour, while opening a window through which the shareholders view the behaviour of the managers. Importantly, these elements of corporate governance mechanisms enhance the confidence of shareholders that agency problems are under control leading to greater confidence in the share price. In turn, greater confidence in the share prices leads to lower bid ask spreads, lower share return volatility and higher share trading volumes as shareholders are more willing to trade on the basis of smaller refinements in their understanding of the value of the shares.

There are some studies that do examine the relation between corporate governance and asymmetric information. However, they usually deal with limited aspects, or individual mechanisms, of corporate governance. Cai et al. (2006), Hillier and McColgan (2006), Kanagaretnam et al. (2007) and Holm and Scholer (2010) find that board independence is inversely related to asymmetric information. Chen and Nowland (2010) suggest that increasing board independence advance the interests of minority investors through mitigating the underinvestment problem. Wruck (1993) and Kang, Kumar and Lee (2006) examine the importance of the form of executive compensation in reducing agency problems and mitigating asymmetric information. Chi and Scott-Lee (2010) show that high amounts of free cash flow strengthen the influence of the quality of corporate governance practices on firm value and Chen et al. (2013) find that external financing needs are 
inversely related to information asymmetry. Belghitar and Khan (2011) suggest that internal governance mechanisms are more effective for enterprises with high growth investment opportunities, while external governance mechanisms, such as capital market monitoring, are more efficient for firms with low growth investment opportunities.

Overall our paper is related to a particular stream of literature that examines the relation between governance quality and corporate boards in specific settings, such as CEO turnovers (Weisbach, (1988)), tender offers (Byrd \& Hickman, (1992)), poison pill adoptions (Brickley, Coles, \& Terry, (1994)), acquisitions (Cotter, Shivdasani, \& Zenner, (1997)), corporate restructuring (Perry \& Shivdasani, (2005)), cost of debt (Francis, et al, (2012)), new product announcement (Lin and Chang, (2012)) and banking sector Dermine (2013).

\section{HYPOTHESES DEVELOPMENT}

The more independent the board is from executive control the more effective the board will be in monitoring senior management. Accordingly, we expect that the more independent the board, the greater confidence shareholders will have that agency problems are under control and the lower will be the spread, volatility and share trading volume. Similarly, the greater technical expertise of the audit committee, the more effective this committee will be in monitoring the accounting system and by implication, agency problems and the performance reward systems. This will lead to greater shareholder confidence in the reported results and greater confidence that agency problems are under control. Finally, Cai et al. (2006) note that in recent years, boards are being pressured into becoming more diverse in the belief that more diverse boards will be more effective monitors of management. Adams and Ferreira (2009) find that gender diverse boards allocate more effort to monitoring. Thus, we expect that the greater the diversity of the board, the more effective the board will be in monitoring management and the greater control will be placed on agency problems leading to lower spreads, volatility and higher share trading volume. In summary our first hypothesis can be stated as follows.

\section{H1. Ceteris paribus, there is an inverse relation between boards that are more independent, expert and diverse and the degree of asymmetric information.}

Our second governance category considers the activeness of the board of directors. More active boards should be more effective monitors of management leading to greater control of agency problems. For example, Kanagaretnam et al. (2007) suggest that boards and committees that meet more frequently are likely to be monitoring management more closely. In turn, more effective monitoring of management will lead to greater control of agency problems and greater shareholder confidence in the share price leading to lower bid ask spreads and volatility and higher trading volumes.

However, board meeting attendance and the number of board meetings can be directly rather than inversely related to measures of asymmetric information 
as higher attendance and more meetings are needed to respond to controversies. Specifically, the surrounding uncertainty regarding the resolution of controversies can cause the bid ask spread and volatility to rise and the trading volume to fall just as more meetings and higher attendance occur to resolve these controversies. Therefore our second hypothesis is as follows.

H2. Ceteris paribus and controlling for controversies, more active boards are inversely associated with measures of asymmetric information.

Our third governance category considers the impact of compensation schemes for senior executives. Performance-related pay is designed to enhance shareholder value by encouraging managers to reveal the level of effort they expend, and to avoid shirking and consuming perquisites. Wruck (1993) shows that companies with investment disincentives have CEO compensation that emphasizes equity ownership relative to other forms of executive compensation. Shleifer and Vishny (1997) suggest that it is better to grant management long term incentives in order to align management's interests with those of investors. Additionally, according to Kang, Kumar and Lee (2006), equity-based compensation is the most powerful means of aligning the interests of the $\mathrm{CEO}$ and shareholders. Compensation packages that reward managerial performance and link compensation to the share price can reduce agency problems because managers are encouraged to increase effort and to avoid excess perquisites in order to increase the share price. Therefore, we expect executives that receive performance related pay will avoid shirking and consuming excess perquisites thereby reducing agency problems. Shareholders will expect this as well so that firms with performance related pay systems will have lower bid ask spreads and volatility and higher trading volumes as shareholders will have greater confidence that agency problems are under control. Consequently, out third hypothesis is as follows.

H3. Ceteris paribus, there is an inverse relation between the presence of compensation packages that include stock compensation and measures of asymmetric information.

The effect of ownership concentration on asymmetric information is uncertain. On the one hand, Shleifer and Vishny (1997), Florackis and Ozkan (2009), Gul et al. (2010), Lin et al. (2011) and Jiang et al. (2011) suggest that large shareholders are effective in supervising management. Leung and Horwitz (2010) show that firms with a more concentrated management (executive board) ownership displayed a better capital market performance during a period of crisis. Correspondingly, Perotti and Thadden (2003) document that dominant investors such as large lenders or large equity holders can improve corporate governance, Boubaker et al. (2014) document that ownership concentration expedites the capitalization of firm-specific information into stock prices and decreases synchronicity and Pawlina and Renneboog (2005) conclude that block-holders appear to play a role in mitigating agency problems. 
On the other hand, more block-holders means more concentrated ownership, where blockholders can influence management to take actions in the blockholders' interests and contrary to the interests of other shareholders. Heflin and Shaw (2000) and O'Neill and Swisher (2003) suggest that greater institutional ownership can cause an increase in adverse selection problems. Carpenter, Indro, Miller and Richards (2010) report an increase in asymmetric information for firms who's CEO has large ownership stakes. Therefore, we cannot predict a priori the sign of the relation between measures of ownership concentration and measures of asymmetric information.

Debt financing can be viewed as a mechanism to mitigate asymmetric information because creditors are motivated to monitor the behaviour of management in order to protect their claims. Degryse and Jong (2006) state that "leverage, and particularly bank debt, is a key disciplinary mechanism which reduces the managerial discretion problem and asymmetric information problem”. Bebchuk (2003) concurs with this, stating that company debt can act as a disciplinary device to limit managerial discretion and asymmetric information, and works towards aligning manager and shareholder interests. Francis et al. (2012) find that loan terms are more favourable for boards that minimize information risk. This leads to our fourth hypothesis:

H4. Ceteris paribus, there is an inverse relation between the level of debt and proxies for asymmetric information.

\section{METHODOLOGY AND DATA DESCRIPTION}

We collect all the corporate governance information that is available on DataStream for the eight corporate governance variables described below and match them by company and year with the corresponding measures of asymmetric information and control variables. We find that there are 376 companies contained in this database all of which are listed on the main board of the London Stock Exchange. We start the data series in 2004 as prior to that year there are very few companies, many of which also have missing values for several of the corporate governance variables. Our database ends in 2010 as that is the last year that was available to us. We chose to exclude financial firms such as Banks, Insurance Companies and other miscellaneous financial firms because of extreme differences in their capital structures and regulatory environment compared with other firms, Switzer and Wang (2013). ${ }^{2}$ We include firms that have since left the database as they have gone bankrupt (e.g., Woolworths), merged (e.g., Boots) or acquired (e.g., Cadbury) to avoid survivorship bias and we include new listings. Table 1 show that the final sample is comprised of 324 UK firms. The largest components by industry are consumer services $(27.16 \%)$, industrials $(25.62 \%)$, and consumer goods $(10.19 \%)$. The consumer services and industrials appear to dominate our sample.

${ }^{2}$ Switzer and Wang (2013) document that corporate governance structures have a greater impact on US commercial banks than on other types of savings institutions. 
Table 1: Sample composition by industry

\begin{tabular}{lcccc}
\hline Industry & Number & Percentage & $\begin{array}{c}\text { DEBT } \\
\text { RATIO }\end{array}$ & $\begin{array}{c}\text { Market Value } \\
\text { (in £ millions) }\end{array}$ \\
\hline Basic Materials & 24 & 7.41 & 16.70 & 9,829 \\
Oil and Gas & 24 & 7.41 & 19.82 & 7,775 \\
Industrials & 83 & 25.62 & 22.55 & 1,443 \\
Consumer Goods & 33 & 10.19 & 23.23 & 5,396 \\
Health Care & 10 & 3.09 & 19.08 & 12,478 \\
Consumer Services & 88 & 27.16 & 31.63 & 2,439 \\
Telecommunication & 5 & 1.54 & 30.31 & 25,388 \\
Utilities & 12 & 3.70 & 42.97 & 6,284 \\
Real Estate & 22 & 6.79 & 39.82 & 1,144 \\
Technology & 23 & 7.10 & 11.52 & 825 \\
Total & 324 & 100.00 & 25.68 & 3,917 \\
\hline
\end{tabular}

Notes: The target population includes all non-financial UK companies listed in DataStream's Corporate Governance Database during the period 2004 to 2010. 'Industry classification' is made according to the nomenclature of the Industry Classification Benchmark developed by Dow Jones. 'Number' refers to the number of companies in a given industry, 'percentage' refers to the percentage of the total sample represented by each industry and total DEBT RATIO and market value reports the respective averages by industry.

Moreover, the tangibility of assets in the industrial as opposed to the service sector is quite different so they may well choose different corporate governance systems. Therefore, we control for industry effects by employing a dummy variable for firms in the CONSUMER SERVICES and INDUSTRIAL industry sectors.

\section{MeAsuring Asymmetric Information}

As there is no generally accepted "best" measure of asymmetric information, we choose four that are most commonly used in the literature: the bid ask spread, volatility, share volume measured at market prices and the number of shares traded. ${ }^{3}$ The definitions of all asymmetric information, governance and control variables and the expected signs of the coefficient's relation to asymmetric information are reported in Appendix A.

Studies by George et al. (1991), Lin, Sanger and Booth (1995), Madhavan, Richardson and Roomans (1997) and Huang and Stoll (1997) analyse the bid-ask spread into its order processing, inventory holding and asymmetric information components. However, Van Ness, Van Ness and Warr (2001) indicate a strong correlation among all the components of the spread while Menyah and Paudyal

\footnotetext{
${ }^{3}$ There are many other proxies for asymmetric information. For example, Van Ness, Van Ness, and Warr (2001) suggest informed trader variables such as the number of analysts covering a given company and the percentage of stock of a given company held by an institution. Kanagaretnam et al (2007) examine other proxies, specifically earnings forecast dispersion, forecast revision volatility, the level of analyst coverage and the change in share trade depth around quarterly earnings releases.
} 
(2000) find that, on the London Stock Exchange, the asymmetric information component dominates the realised spread. ${ }^{4}$ Taken together, these studies suggest that the adverse selection component behaves in much the same way as the entire spread, and so justifies the use of the bid-ask spread as a proxy variable for asymmetric information. Thus, we assume that the larger the SPREAD, the percentage change in the bid ask spread as reported by DataStream, the larger will be the degree of asymmetric information.

Van Ness et al. (2001) use the average volatility of daily stock returns in addition to the bid-ask spread as a proxy for information asymmetry. Wang (1993) shows that information asymmetry among investors can increase volatility, although volatility can overstate the level of asymmetric information. Accordingly, we assume that the higher the average volatility in stock returns VOLATILITY, the higher will be the degree of asymmetric information.

We use share trading volume as our third measure, since Draper and Paudyal (2008) indicate that the average trading volume is inversely related to asymmetric information. According to Van Ness et al. (2001), average trading volume is related to information asymmetry because less is known about less frequently traded stocks. Acker, Stalker and Tonks (2002) report that high trading volumes are associated with closing prices that are more often within the daily spread and indicates lower levels of information asymmetry. Gajewski (1999) finds that trading volume is larger on announcement days, suggesting that higher trading volumes are associated with the possible release of information. Hence, we expect that the higher the average trading volume, the lower will be the degree of asymmetric information. As trading volume can be measured according to the number of shares or the value of shares traded we chose to measure trading volume both ways. Therefore TRADE VOLUME is the number of shares traded for a company in a given year normalised by the number of shares in issue whereas TRADE VALUE is the market value of a stock traded for a company in a given year, both of which are decreasing in asymmetric information.

Finally, as a robustness check, we construct a composite variable of the above conventional measures of asymmetric information COMPOSITE. We conduct a principal component analysis of SPREAD, VOLATILITY, TRADE VOLUMNE and TRADE VALUE and find that the first principal component of these four variables explains approximately $94.5 \%$ of the total variation of this data. This suggests that the first component can form a good summary variable of these four different measures of asymmetric information that can be used as a robustness check on the relation between asymmetric information and corporate governance. ${ }^{5}$ We expect that COMPOSITE is increasing in asymmetric information because COMPOSITE

\footnotetext{
${ }^{4}$ Menyah and Paudyal (2000) find that on the LSE on average $30 \%$ of the spread is the order processing, $23 \%$ is inventory and $47 \%$ is the asymmetric information components.

${ }^{5}$ The composite variable is measured from the correlation matrix. We standardize each observation of SPREAD, VOLATILITY, TRADE VOLUMNE and TRADE VALUE and, for each row of observations; we multiply them by the first principal component's eigenvector and sum the products to find the composite variable's value for a given observation.
} 
is positively associated with SPREAD and VOLATILITY and inversely associated with TRADE VOLUMNE, relations that are the same as those between these proxies and asymmetric information.

\section{Measuring Corporate Governance}

We develop eight proxies for corporate governance, grouped into five categories. Specifically, the five categories are board composition, board activity, executive compensation, ownership concentration and debt financing. We also incorporate two control variables, MARKET VALUE to control for firm size and the number of controversies CONTROVERCIES to control for unusual events. Our model for dealing with self-selection also controls for industry effects by employing dummy variables for INDUSTRIAL and CONSUMER SERVICES firms.

According to our first hypothesis, there is an inverse relation between boards that are more independent, expert and diverse and the degree of asymmetric information. We use three variables that measure the independence, expertise and diversity of the board of directors. These are the percentage of independent members serving on the board of directors INDEPENDENCE, the expertise of the members of the audit committee EXPERT and the percentage of females on the board of directors FEMALE. The greater the percentage of independent members on the board of directors, the more independent the board will be from executive control and the more effective the board will be in monitoring senior management. Accordingly, we expect that the larger the percentage of independent members serving on the board of directors, the greater confidence shareholders will have that agency problems are under control and the lower will be the spread, volatility and share trading volume.

We wish to determine whether the technical expertise of the audit committee also leads to greater confidence in the share price. DataStream compiles a ranking of the audit committee's expertise EXPERT. Key considerations are the existence of an audit committee, the number of independent members and the number of members that can be considered a financial expert within the meaning of the Sarbanes-Oxley Act. Evidently, the Financial Reporting Council supported by evidence from Chahine and Filatochev (2011) believes that the greater technical expertise of the audit committee, the more effective this committee will be in monitoring the accounting system and by implication, agency problems and the performance reward systems. This will lead to greater shareholder confidence in the reported results and greater confidence that agency problems are under control. Therefore, we expect an inverse relation for audit committee expertise EXPERT and proxies for asymmetric information.

Finally, Cai et al. (2006) and Adams and Ferreira (2009) suggest that gender diverse boards allocate more effort to monitoring. Thus, we expect that the greater the fraction of females on the board FEMALE, the more effective the board will be in monitoring management and the greater control will be placed on agency problems leading to lower spreads, volatility and higher share trading volume. 
Our second hypothesis suggests that, controlling for controversies, more active boards are inversely associated with measures of asymmetric information. We proxy the activeness of the board as the annual number of meetings of the board of directors BOARD MEETS and the overall percentage attendance of members of the board ATTENDANCE. Therefore, there should be an inverse association between measures of asymmetric information and more frequent board meetings with higher attendance. However, board meeting attendance and the number of board meetings can be directly rather than inversely related to measures of asymmetric information as higher attendance and more meetings are needed to respond to controversies. Therefore, to control for this effect we include a variable CONTROVERCIES that counts the number of times during the year the company had a controversy as reported in the financial press. We expect the value of this coefficient to be positively related to the bid ask spread and volatility and inversely related to share trading volume.

According to our third hypothesis, we expect an inverse relation between the presence of compensation packages that include stock compensation and measures of asymmetric information. We use a dummy variable STOCK COMPENSATION that takes on the value of one if senior executives receive compensation in the form of stock. Therefore, we expect that the STOCK COMPENSATION coefficient is negative. In contrast, the effect of ownership concentration on asymmetric information is uncertain as the relation can be inverse if dominate shareholders are more effective monitors of management or the relation can be positive if there is a fear that dominate shareholders influence management to take actions to their benefit against smaller shareholders' interests. Therefore our measure of ownership concentration, the single largest percentage ownership by an investor BIG OWN, can be positive or negative.

Finally, our fourth hypothesis suggests that is an inverse relation between the level of debt and proxies for asymmetric information as larger debt incentivises debt holders to monitor management. We use the total debt to total assets ratio DEBT RATIO, measured as of the beginning of the year, as a proxy for the level of debt financing and expect the coefficient to be negative.

Table 2 provides the Pearson correlations between the corporate governance and the continuous asymmetric information variables. Virtually all correlations are fairly low indicating that collinearity is not likely to be a problem. The exceptions are the correlations of TRADE VOLUMNE and TRADE VALUE measures of asymmetric information with MARKET VALUE. This highlights the importance of including MARKET VALUE as a control variable. Moreover, the correlation between TRADE VALUE and TRADE VOLUMNE is also high. This motivates us to include the principal component derived COMPOSITE variable as a fifth proxy for asymmetric information. We then use COMPOSITE as a robustness check to determine if a linear combination of these variables as well as SPREAD and VOLATILITY can reinforce the conclusions obtained by separately using the first four proxies for asymmetric information. 
138 Ahmed Elbadry et al.

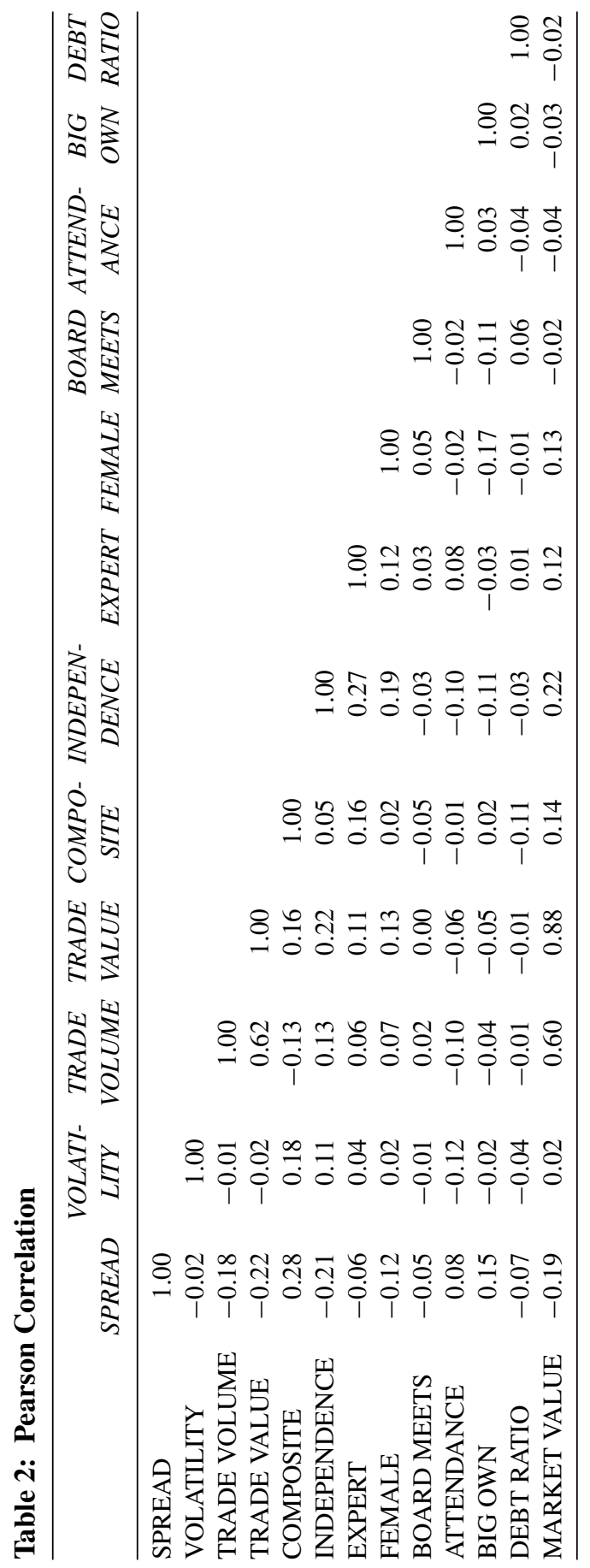




\section{THE MODEL}

We collect a panel data series for all 324 firms annually from 2004 to 2010, potentially 2,268 observations. We have about half of these potential observations because of the turnover of listed companies for the reasons outlined above. Consequently, our unbalanced panel data has a large number of individuals, 324 companies, and a small time series, at most seven years. We conduct a Hausman specification test finding that the coefficients estimated via random and again using fixed effects estimators are not statistically different. ${ }^{6}$ Based on this test, we follow the recommendations of Judge, Griffiths, Hill, Lutkepohl \& Lee (1985), page 527-9, and use the random effects estimator. Moreover, an analysis of variance test does reveal clear evidence of time effects. For these reasons, we intend to fit a random effects model adjusted for time effects.

We wish to determine the effect corporate governance choice has on the degree of asymmetric information. The relation between corporate governance and asymmetric information can be endogenous as choices made in the design of corporate governance systems can be influenced by the degree of asymmetric information faced by the corporation and by industry membership. Therefore, we must adjust our inquiry for self-selection bias.

Heckman (1979) provides the methodology for dealing with self-selection bias by treating the problem as a case of an omitted variable. We follow Heckman's (1979) two stage procedure by first running a probit selection equation to extract the inverse mills ratio and then use the inverse mills ratio as an independent variable in an asymmetric information regression. The inverse mills ratio is presumed to proxy for the influence of self-selection. The inverse mills ratio then serves as a correction in the asymmetric information regression as it accounts for the influence of self-selection on asymmetric information. Then, the second stage asymmetric information regression can measure the relation among proxies for corporate governance and asymmetric information free of endogeneity caused by self-selection.

Our selection equation investigates determinates of the quality of corporate governance. The selection equation is

$$
P(G=1)=F\left(\begin{array}{l}
{\text { Constant }+ \text { INDENENDENCE }_{\mathrm{i}, \mathrm{t}}+\text { EXPERT }_{\mathrm{i}, \mathrm{t}}} \text { FEMALE }_{\mathrm{i}, \mathrm{t}}+\text { ATTENDANCE }_{\mathrm{i}, \mathrm{t}} \\
+ \text { BOARD MEETS }_{\mathrm{i}, \mathrm{t}}+\text { STOCK COMPENSATION }_{\mathrm{i}, \mathrm{t}} \\
+ \text { BIG OWN }_{\mathrm{i}, \mathrm{t}}+\text { DEBT RATIO }_{\mathrm{i}, \mathrm{t}} \\
+ \text { MARKET VALUE }_{\mathrm{i}, \mathrm{t}}+\text { INDUSTRIAL }_{\mathrm{i}, \mathrm{t}} \\
+ \text { CONSUMER SERVICES }_{\mathrm{i}, \mathrm{t}}+\varepsilon_{\mathrm{i}, \mathrm{t}}
\end{array}\right)
$$

\footnotetext{
${ }^{6}$ For 11 degrees of freedom, the critical value of the Hausman chi-square statistic at the $10 \%$ significance level is 19.81 . We obtain chi-square statistics of $1.37,5.34,2.80$ and 0.17 respectively for the random versus fixed effects estimators for the spread, volatility, trade volume and trade value panel regressions of (2) so we are unable to reject the null hypothesis of random effects at even the $10 \%$ level.
} 
where $\mathrm{i}$ refers to a given firm and $\mathrm{t}$ a given year, and $\mathrm{G}$ is a dummy variable that takes on the value of 1 if the quality of the company's corporate governance is greater than or equal to the median score for the quality of corporate governance for firms listed on the London Stock Exchange, zero otherwise.

All else equal, we expect that larger firms MARKET VALUE will have a stronger corporate governance system as larger firms, being high profile, are likely more pressured into developing highly sophisticated corporate governance systems and can also afford to do so. Firms in the CONSUMER SERVICES sector can find it difficult to achieve high rankings for corporate governance because the asset structure of firms in the consumer service sector tend to be shorter term, less easily verifiable with less debt capacity than other firms. For the same reasons, INDUSTRIAL firms can find it easier to score high rankings for corporate governance. We estimate (1) using the maximum likelihood probit regression technique using robust standard errors.

The asymmetric information regression contains the governance and control variables that we expect to determine the degree of asymmetric information.

$$
\begin{aligned}
Y_{j, i, t}= & \alpha+\beta \text { INDEPENDENCE }_{\mathrm{j}, \mathrm{i}, \mathrm{t}}+\beta \text { EXPERT }_{\mathrm{j}, \mathrm{i}, \mathrm{t}} \\
& +\beta \text { FEMALE }_{\mathrm{j}, \mathrm{i}, \mathrm{t}}+\beta \text { ATTENDANCE }_{\mathrm{j}, \mathrm{i}, \mathrm{t}} \\
& +\beta \text { BOARD MEETS }_{\mathrm{j}, \mathrm{i}, \mathrm{t}}+\beta \text { CONTROVERCIES }_{\mathrm{j}, \mathrm{i}, \mathrm{t}} \\
& +\beta \text { STOCK COMPENSATION }_{\mathrm{j}, \mathrm{i}, \mathrm{t}}+\beta \text { BIG OWN }_{\mathrm{j}, \mathrm{i}, \mathrm{t}} \\
& +\beta \text { DEBT RATIO }_{\mathrm{j}, \mathrm{i}, \mathrm{t}}+\beta \text { MARKET VALUE }_{\mathrm{j}, \mathrm{i}, \mathrm{t}} \\
& +\beta \text { MILLS RATIO }_{\mathrm{j}, \mathrm{i}, \mathrm{t}}+\varepsilon_{\mathrm{j}, \mathrm{i}, \mathrm{t}}
\end{aligned}
$$

where:

$\mathbf{j}=\mathbf{1}=$ SPREAD,

$\mathbf{j}=\mathbf{2}=$ VOLATILITY,

$\mathbf{j}=\mathbf{3}=$ TRADE VOLUME,

$\mathbf{j}=\mathbf{4}=$ TRADE VALUE,

$\mathbf{j}=\mathbf{5}=$ COMPOSITE

and $\alpha$ is the regression intercept, $\varepsilon_{\mathrm{j}, \mathrm{i}, \mathrm{t}}$ is the random error term for each regression $\mathrm{j}$ and company $\mathrm{i}$ and date $\mathrm{t}$ and MILLS RATIO is the estimated inverse mill's ratio from (1). All other variables are as previously defined. Accordingly, we study the effect of corporate governance variables on proxies for asymmetric information using five (j) panel regression models on 324 (i) companies of (potentially) seven (t) time series observations each using a random effects estimator adjusted for time effects all of which are corrected for self-selection bias. 
Table 3a: Corporate Governance and Asymmetric Information: Main Results

\begin{tabular}{|c|c|c|}
\hline \multirow{2}{*}{$\begin{array}{l}\text { Governance Selection Equation } \\
\text { Variable }\end{array}$} & \multicolumn{2}{|c|}{ Governance $(G)$} \\
\hline & Coefficient & T-Statistic \\
\hline CONSTANT & $-3.41^{* * *}$ & -3.54 \\
\hline INDEPENDENCE & $0.02^{* * *}$ & 3.79 \\
\hline ATTENDANCE & -0.01 & -1.61 \\
\hline BOARD MEETS & $0.04^{* *}$ & 2.76 \\
\hline EXPERT & -0.00 & -1.20 \\
\hline FEMALE & $0.02^{* * *}$ & 2.96 \\
\hline STOCK COMPENSATION & $0.42^{* *}$ & 2.41 \\
\hline BIG OWN & $-0.03^{* * *}$ & -6.19 \\
\hline DEBT RATIO & 0.43 & 1.61 \\
\hline MARKET VALUE & $0.51^{* * *}$ & 10.61 \\
\hline INDUSTRIAL & $0.30^{* *}$ & 2.60 \\
\hline CONSUMER SERVICES & $-0.41^{* * *}$ & -3.31 \\
\hline $\mathrm{N}$ & 924 & \\
\hline $\mathrm{R}-$ Squared & 0.35 & \\
\hline
\end{tabular}

\section{EMPIRICAL ANALYSIS}

Table 3a presents the results of the selection equation (1). These estimates show that governance systems that receive the highest ranking are the ones that have more independent INDEPENDENT, active BOARD MEETS and diverse FEMALE boards that reward senior executive with STOCK COMPOSITION. Firms with larger inside ownership BIG OWN have lower rankings. Meanwhile, larger firms MARKET VALUE receive higher rankings than smaller firms, firms with tangible assets INDUSTRIAL receive higher rankings and firms with fewer tangible assets CONSUMER SERVICES receive lower rankings than other firms.

Table $3 \mathrm{~b}$ reports the associated asymmetric information regression for five measures of asymmetric information. While all regressions explain the relation between asymmetric information and proxies for corporate governance to some extent, the R-square of the model for TRADE VALUE is noticeably higher than the corresponding R-squares for the other four proxies for asymmetric information. ${ }^{7}$ Evidently, self-selection bias is not present for the SPREAD, VOLATILITY and TRADE VALUE measures of asymmetric information as the MILLS RATIO is not statistically significant. However, we detect the presence of self-selection in the TRADE VOLUME and COMPOSITE measures of asymmetric information.

${ }^{7}$ It is possible that the high $\mathrm{R}$ square of this regression is due to the correlation between MARKET VALUE and TRADE VOLUME. Replacing MARKET VALUE of the firm with the book value of the firm does not make a material difference however, as the book value of the firm is highly correlated with its market value $(+0.7)$. 


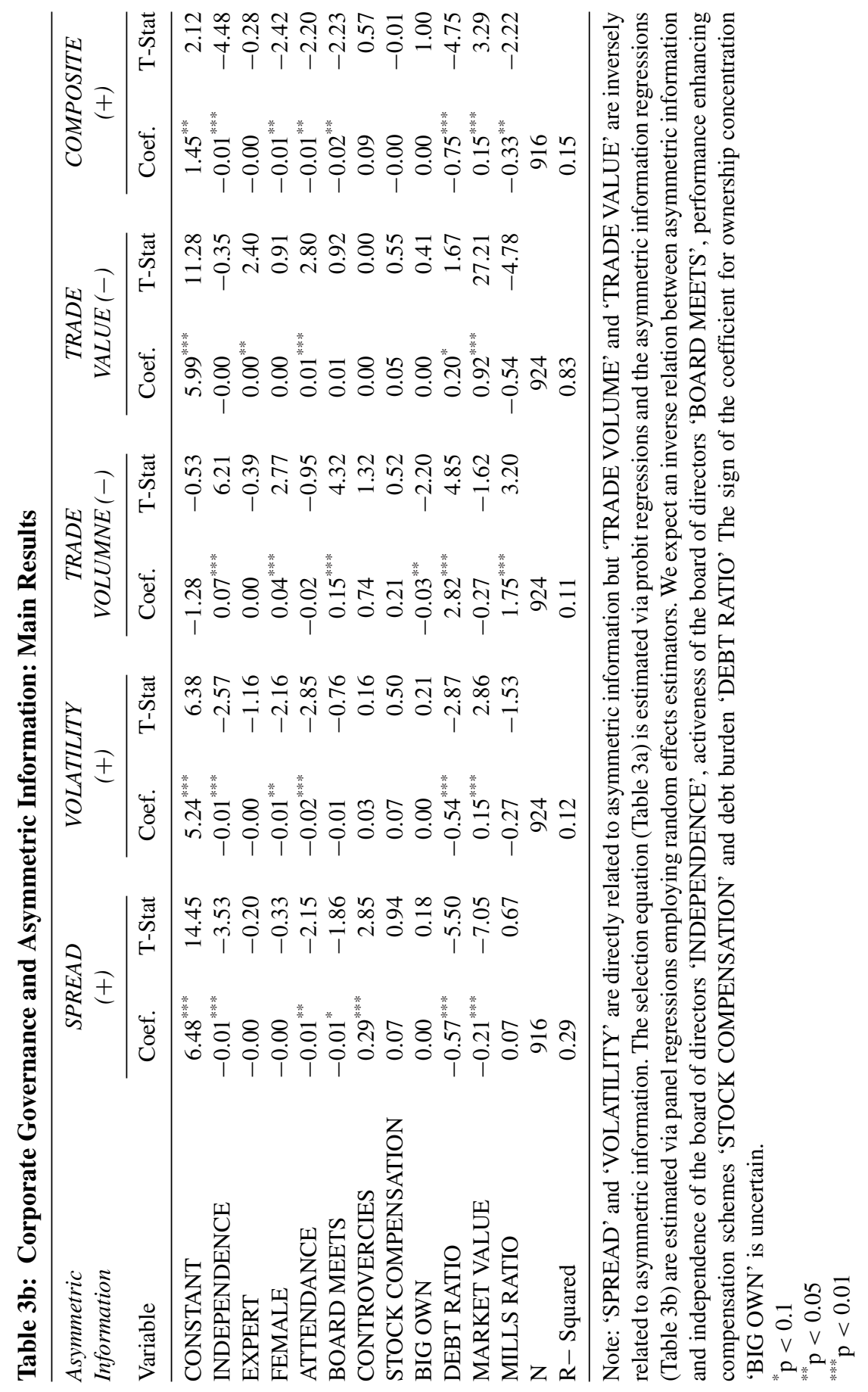


Finally, MARKET VALUE is highly significant in four instances clearly highlighting the importance of including this variable as a control variable. Evidently, larger companies have a lower bid ask spread and higher volatility and trading values.

\section{BOARD COMPOSITION}

We find strong support for H1. All five regressions show that there is a significant inverse relation between at least one proxy for best practise in the board structure and the degree of asymmetric information in the market for the firm's shares. Specifically, board independence INDEPENDENCE is inversely related to SPREAD, VOLATILITY, TRADE VOLUME and COMPOSITE, diverse FEMALE boards are inversely related to VOLATILITY, TRADE VOLUME and COMPOSITE and finally, EXPERT boards are inversely related to TRADE VALUE measures of asymmetric information.

\section{BOARD ACTIVITY}

We find strong support for $\mathrm{H} 2$ as once we correct for the confounding effects of CONTROVERCIES, active boards are inversely related to proxies for asymmetric information. ATTENDANCE is significantly related to SPREAD, VOLATILITY, TRADE VALUE and COMPOSITE and BOARD MEETS is significantly related to SPREAD, TRADE VOLUME and COMPOSITE, meaning that more frequent and well attended board meetings are inversely associated with proxies for asymmetric information. Interestingly, the number of CONTROVERCIES reported in the financial press for the year is directly associated with SPREAD. If we remove this variable, BOARD MEETS and ATTENDANCE often drop in significance in Table $3 \mathrm{~b}$ and falls from significant to insignificant in some of the later robustness regressions. This indicates that indeed it is valuable to control for controversies because extra meetings can be scheduled to deal with crisis reported in the financial press thereby obscuring the usual relation that frequent and well attended board meetings are inversely associated with measures of asymmetric information.

\section{Executive Compensation and Ownership Concentration}

Interestingly, we find that ownership concentration BIG OWN is directly related to TRADE VOLUME, otherwise this variable is not significantly related to any other measure of asymmetric information. This suggests that ownership concentration, rather than playing a monitoring role in reducing asymmetric information, actually leads to greater anxiety on behalf of smaller shareholders suspecting that management are persuaded to take actions that benefit large block-holders at the expense of smaller shareholders. We find no support for $\mathrm{H} 3$ as we find that compensation schemes that are designed to encourage performance are not related to any of our measures of asymmetric information. 


\section{Debt FinANCing}

Finally, H4 has strong support as we find that debt financing is inversely related to proxies for asymmetric information. Our proxy for debt financing DEBT RATIO is statistically significant and of the correct sign for all proxies for asymmetric information. Evidently, shareholders believe that lenders play an important monitoring role as they periodically examine compliance with debt covenants and so shareholders have greater confidence that agency problems are under control.

\section{Parsimonious Models}

We form a parsimonious asymmetric information regression model consisting of the same control variables as (2) but with one proxy each for the five elements of corporate governance. Specifically, we drop the proxies ATTENDANCE, EXPERT and FEMALE leaving INDEPENDENCE, BOARD MEETS, STOCK COMPENSATION, BIG OWN and DEBT RATIO to proxy respectively, board composition, board activity, compensation schemes, ownership concentration and debt financing elements of corporate governance. ${ }^{8}$ This step is necessary for the robustness work since we need to subdivide the sample in several ways so that in some cases the full regression model has a small sample size. The parsimonious model always has more data points so that we are always able to obtain reliable estimates that are comparable across sub-samples. To be consistent, we adjust the selection model by maintaining the same control variables as in (1) but using the same five proxies for governance used in the parsimonious asymmetric information regression.

Table 4a shows that the parsimonious probit model estimates are virtually the same as the full probit model estimates of Table 3a except that DEBT RATIO is now statistically significant and that the pseudo R-square is slightly smaller, $33 \%$ as opposed to $35 \%$ in Table $3 \mathrm{a}$. The parsimonious asymmetric information regressions are very similar to the full model estimates presented in Table $3 \mathrm{~b}$ except that BIG OWN is now only close to the $10 \%$ significance level in the TRADE VOLUME regression, the marginally significant BOARD MEETS in the SPREAD regression is now not significant and the previously significant BOARD MEETS in the COMPOSITE regression is now only close to the $10 \%$ significance level in Table 4b. Otherwise, what was statistically significant in the full model is statistically significant is the parsimonious model with R-squares that are very similar. Overall, we find that the results of the parsimonious two step model are very similar to the full model giving us confidence that the parsimonious model can used in our robustness work.

\footnotetext{
${ }^{8} \mathrm{We}$ choose these five proxies for corporate governance as this combination obtained the largest sample size as well as the highest pseudo R-square and R-square in the selection and asymmetric information regressions, suggesting that of the available proxies, this combination explained the relation between asymmetric information and asymmetric information the best.
} 
Table 4a: Corporate Governance and Asymmetric Information: Parsimonious Results

\begin{tabular}{|c|c|c|}
\hline \multirow{2}{*}{$\frac{\text { Governance Selection Equation }}{\text { Variable }}$} & \multicolumn{2}{|c|}{ Governance $(G)$} \\
\hline & Coefficient & T-Statistic \\
\hline CONSTANT & $-5.06^{* * *}$ & -12.35 \\
\hline INDEPENDENCE & $0.01^{* * *}$ & 3.92 \\
\hline BOARD MEETS & $0.05^{* * *}$ & 4.27 \\
\hline STOCK COMPENSATION & $0.29^{* *}$ & 2.01 \\
\hline BIG OWN & $-0.03^{* * *}$ & -6.78 \\
\hline DEBT RATIO & $0.46^{*}$ & 1.95 \\
\hline MARKET VALUE & $0.55^{* * *}$ & 12.50 \\
\hline INDUSTRIAL & $0.24^{* *}$ & 2.28 \\
\hline CONSUMER SERVICES & $-0.32^{* * *}$ & -2.83 \\
\hline $\mathrm{N}$ & 1042 & \\
\hline R-Squared & 0.33 & \\
\hline
\end{tabular}

\section{ROBUSTNESS TESTS}

Tables 5 and 6 present the results of our robustness checks. We examine the robustness of our results by economic conditions and by year of analysis. We examine the results by economic conditions because our dataset encompasses a radical shift from boom to bust economic conditions as the financial crisis of 2007 translated into a recession in 2008 and very slow and uncertain growth since. We examine the results by calendar year because we wish to explore whether any annual effect is driving our results, particularly since 2008, being the epicentre of a severe recession can have an unusual influence. For all our robustness work, we first estimate the parsimonious version of (1) as reported in Table 4a, then we extract the inverse mills ratio from this regression and finally we employ this inverse mills ratio as an independent variable in the parsimonious asymmetric information regressions to correct for possible self-selection bias.

Table 5 confirms that the change in economic conditions does not change the main story as reported in Tables $3 \mathrm{~b}$ and $4 \mathrm{~b}$. For example, in Table 5 panel A, the TRADE VOLUME regression in the 2004 to 2007 period reports that proxies for board composition INDEPENDENCE, board activity BOARD MEETS and debt financing DEBT RATIO are inversely related to proxies for asymmetric information just as they are in the corresponding parsimonious regression in Table $4 \mathrm{~b}$. These results are repeated in Table 5 panel B for the 2008 to 2010 recession and slow growth economic period. However, there does appear to be some differences in the details. In the second period, STOCK COMPENSATION is inversely related to asymmetric information for the TRADE VOLUME measure of asymmetric information, but perversely positive (albeit marginally significant) for the SPREAD measure of asymmetric information. Another interesting difference is that ownership concentration BIG OWN is directly related to asymmetric information thereby lending support to Carpenter, Indro, Miller and Richards (2010) 


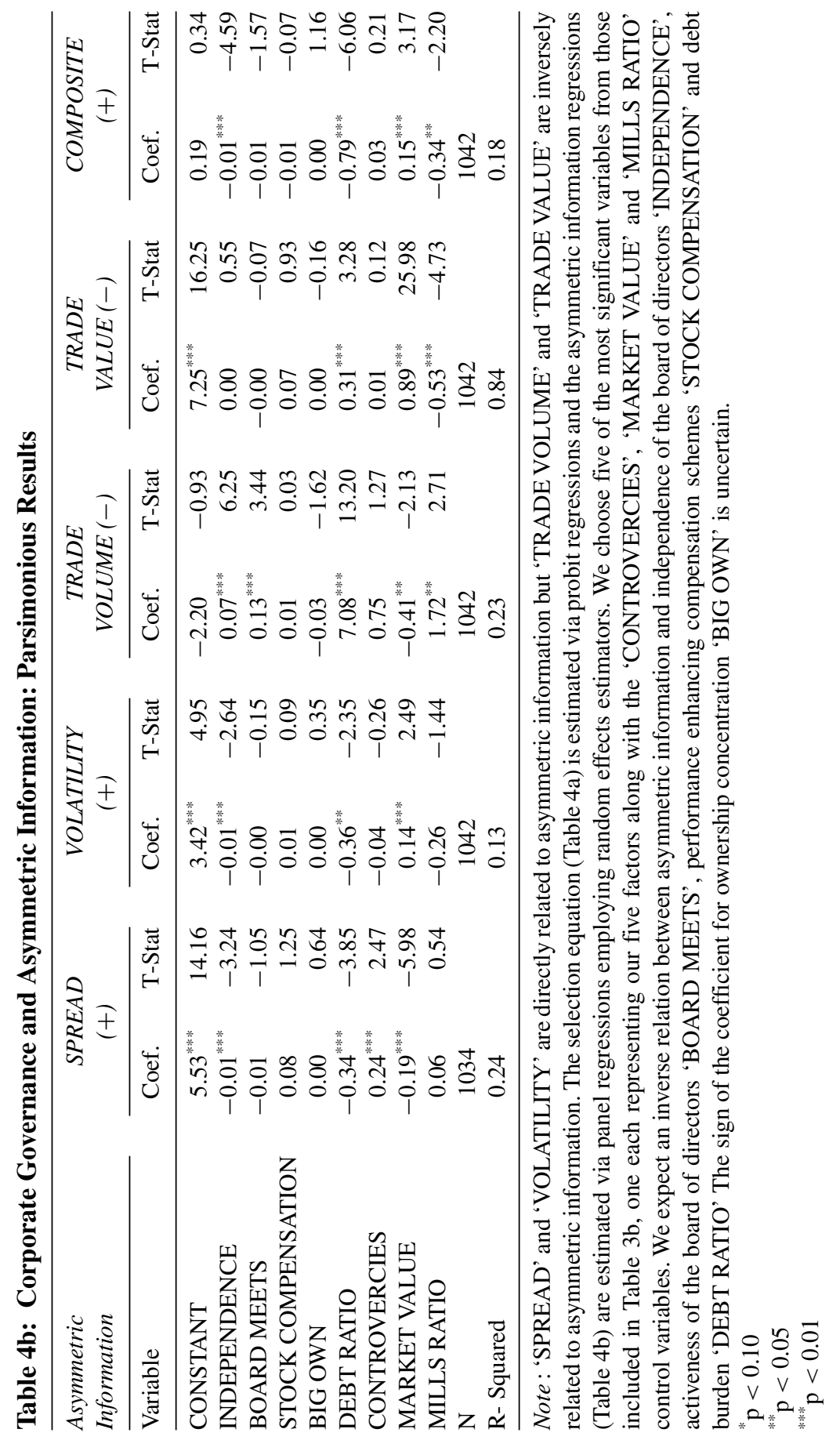




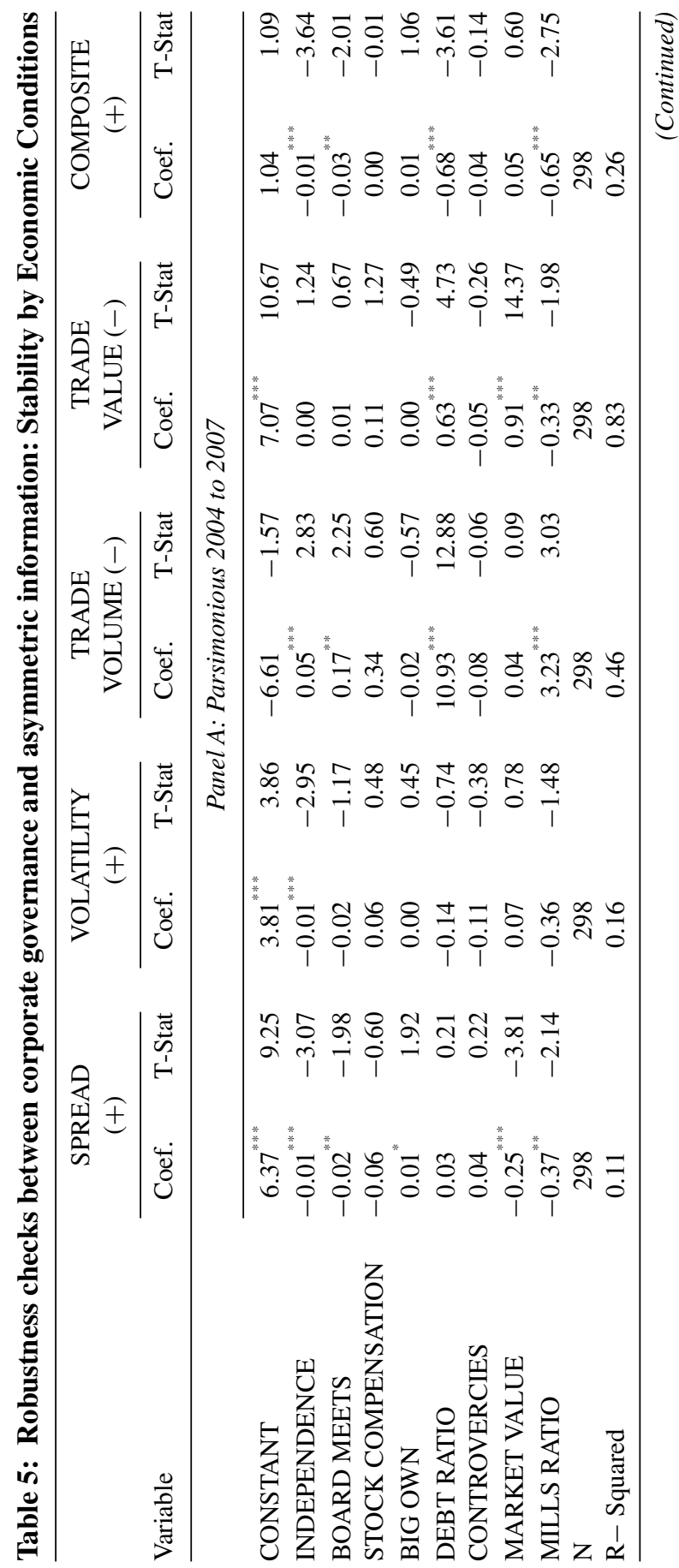




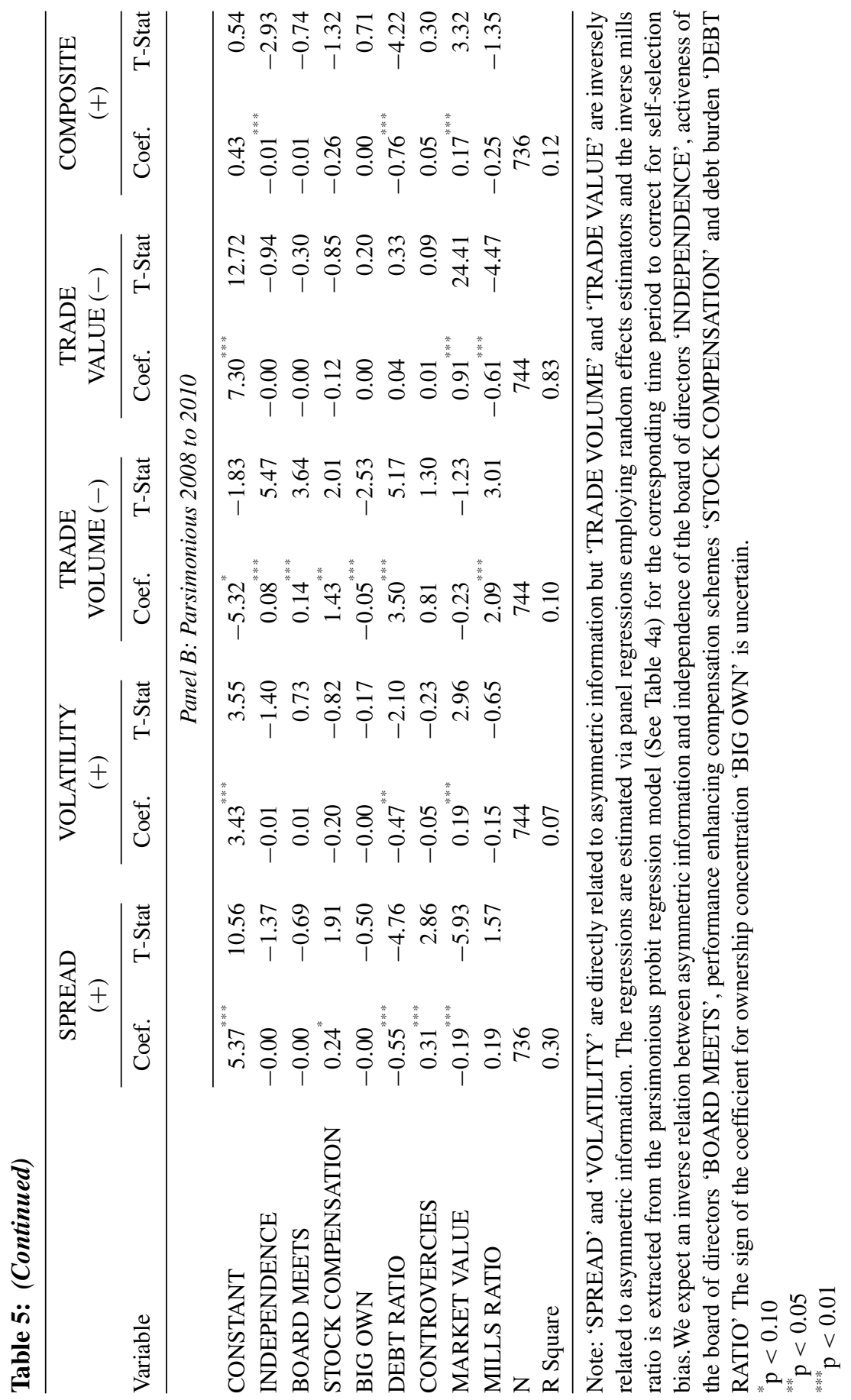




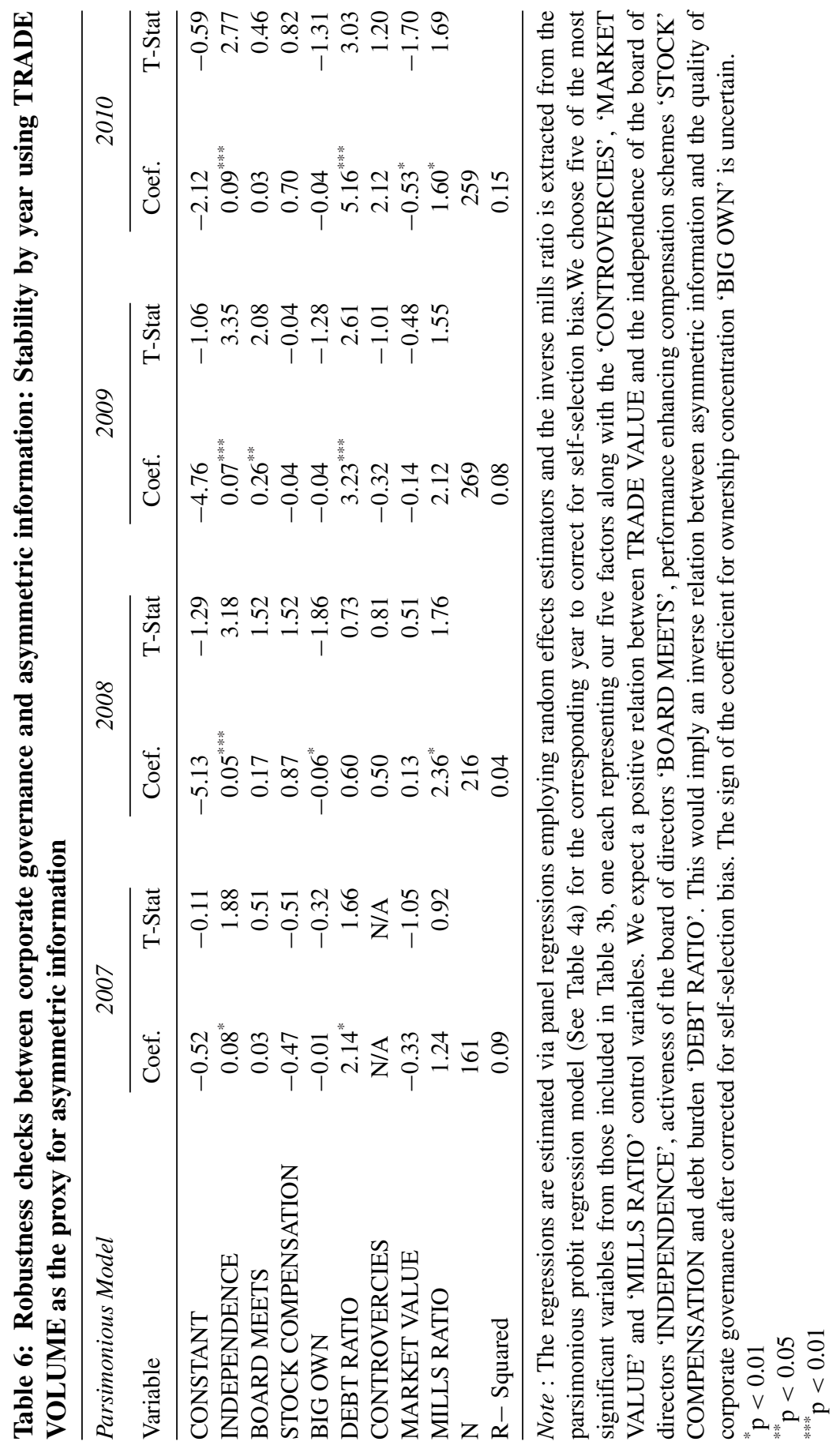


who report an increase in asymmetric information for firms who's CEO has large ownership stakes.

We use TRADE VOLUME as the proxy for asymmetric information in the year by year analysis because Tables 3, 4 and 5 consistently show that TRADE VOLUME is the most useful measure for asymmetric information as it appears to be most closely associated with aspects of corporate governance no matter what set of economic conditions apply. Table 6 shows that our results are not dominated by any given calendar year. ${ }^{9}$ It is interesting to note however, that the direct relation between ownership concentration BIG OWN and asymmetric information is concentrated in the 2008 calendar year. This hints that ordinary shareholders were anxious that major shareholders could influence management to take actions in the interests of major shareholders and contrary to the interests of other shareholders during the recessionary conditions that prevailed in 2008. The independence of the board of directors appears significant in every single year. This empirical result is consistent with the rationale that outside directors are selected on average in the interest of the shareholders.

\section{SUMMARY AND CONCLUSION}

Using a sample of 324 non-financial UK companies from 2004 to 2010, we examine the relation among corporate governance mechanisms and asymmetric information. While corporate governance mechanisms are designed to mitigate agency problems, they can also alleviate investor's concerns regarding an agency problem information asymmetry. Specifically, shareholders are well aware that managers can impose agency problems through shirking and consuming excess perquisites but unlike the managers, shareholders are uncertain as to the extent of these problems. We examine whether, after correcting for self-selection bias, adopting best practise in corporate governance alleviates investors' concerns regarding agency problems, thereby enhancing their confidence in the valuation of the company and improving the informational environment of the firm.

We find evidence that there is an inverse relation between best practice corporate governance mechanisms and asymmetric information. Evidently, governance mechanisms that enhance the monitoring role of the board of directors and use debt to monitor management, improves the market for the firm's shares by reducing the bid ask spread and stock return volatility and by increasing share trading volume. This suggests that shareholders are more confident that agency problems are under control when a firm adopts best practise corporate governance so are more willing to trade in the firms shares.

Specifically, after correcting for self-selection bias, and controlling for industry and size effects, we find that independent and active boards as well as the use of debt financing are all inversely related to a variety of proxies for asymmetric information. In contrast, we find little evidence of a significant relation between

\footnotetext{
${ }^{9}$ Note that we are unable to estimate a reliable cross sectional regression for calendar years prior to 2007 because some key variables such as INDEPENDENCE and AUDIT are missing too often so that the sample size is not comparable to the reported regressions.
} 
performance related pay and greater ownership concentration with information asymmetry. These results are robust with respect to a variety of measures of asymmetric information, to economic conditions and to the year of analysis.

This study is limited in that it focuses on UK non-financial firms suggesting that future research could extend this study to other developed or developing countries. Moreover it would be interesting to explore the relation between corporate governance and asymmetric information for the financial sector. Additionally, the importance of debt financing suggests that perhaps large creditors can play an important monitoring role, an issue that has yet to be explored.

\section{APPENDIX A}

VARIABLES AND DEFINITIONS

\begin{tabular}{|c|c|c|}
\hline Variable & $\begin{array}{l}\text { Expected } \\
\text { relation with } \\
\text { asymmetric } \\
\text { information }\end{array}$ & Definition \\
\hline SPREAD & $(+)$ & $\begin{array}{l}\text { Asymmetric information } \\
\text { The percentage change in the bid ask } \\
\text { spread from the previous day to today } \\
\text { averaged over the year. }\end{array}$ \\
\hline VOLATILITY & $(+)$ & $\begin{array}{l}\text { The annual average of daily stock return } \\
\text { volatility }\end{array}$ \\
\hline TRADE VOLUME & $(-)$ & $\begin{array}{l}\text { The number of shares traded for a stock in } \\
\text { a given year divide by the number of } \\
\text { shares in issue. }\end{array}$ \\
\hline TRADE VALUE & $(-)$ & $\begin{array}{l}\text { The market value of a stock traded in a } \\
\text { given year, in millions }\end{array}$ \\
\hline COMPOSITE & $(+)$ & $\begin{array}{l}\text { The first principal component of SPREAD, } \\
\text { VOLATILITY, TRADE VOLUME and } \\
\text { TRADE VALUE based on the } \\
\text { correlation among them. } \\
\text { Governance quality }\end{array}$ \\
\hline G & & $\begin{array}{l}\text { A dummy variable that takes on the value } \\
\text { of } 1 \text { if the quality of the company's } \\
\text { corporate governance is judged by } \\
\text { DataStream to be greater than or equal } \\
\text { to the median score for the quality of } \\
\text { corporate governance for firms on the } \\
\text { FTSE } 100 \text {, zero otherwise. }\end{array}$ \\
\hline
\end{tabular}




\begin{tabular}{|c|c|c|}
\hline Variable & $\begin{array}{l}\text { Expected } \\
\text { relation with } \\
\text { asymmetric } \\
\text { information }\end{array}$ & Definition \\
\hline & & Board Composition \\
\hline INDEPENDENCE & $(-)$ & Percentage of independent board members \\
\hline EXPERT & $(-)$ & $\begin{array}{l}\text { A percentage ranking by DataStream. Key } \\
\text { considerations are the existence of an } \\
\text { audit committee, the number of } \\
\text { independent members and the number of } \\
\text { members meeting the criteria of } \\
\text { "financial expert" within the meaning of } \\
\text { the Sarbanes-Oxley Act. }\end{array}$ \\
\hline \multirow[t]{2}{*}{ FEMALE } & $(-)$ & $\begin{array}{l}\text { Percentage of women on the board of } \\
\text { directors }\end{array}$ \\
\hline & & Board Activity \\
\hline BOARD MEETS & $(-)$ & $\begin{array}{l}\text { The number of board meetings during the } \\
\text { year }\end{array}$ \\
\hline \multirow[t]{2}{*}{ ATTENDANCE } & $(-)$ & $\begin{array}{l}\text { The average overall attendance percentage } \\
\text { at board meetings }\end{array}$ \\
\hline & & Compensation Schemes \\
\hline STOCK COMPENSATION & $(-)$ & $\begin{array}{l}\text { A dummy variable that takes on the value } \\
\text { of } 1 \text { if senior executives receive } \\
\text { compensation in stock, zero otherwise } \\
\text { Ownership concentration }\end{array}$ \\
\hline BIG OWN & $(?)$ & $\begin{array}{c}\text { Single biggest owner ownership percentage } \\
\text { Debt Financing }\end{array}$ \\
\hline DEBT RATIO & $(-)$ & $\begin{array}{l}\text { The beginning of year annual ratio of total } \\
\text { debt to total assets }\end{array}$ \\
\hline & & Control variables \\
\hline INDUSTRIAL & & $\begin{array}{l}\text { A dummy variable that takes on the value } \\
\text { of } 1 \text { if the industry classification of the } \\
\text { firm is industrial, zero otherwise }\end{array}$ \\
\hline CONSUMER SERVICES & & $\begin{array}{l}\text { A dummy variable that takes on the value } \\
\text { of } 1 \text { if the industry classification of the } \\
\text { firm is consumer service, zero otherwise }\end{array}$ \\
\hline CONTROVERCIES & $(+)$ & $\begin{array}{l}\text { The number of times a company had a } \\
\text { controversy reported in the financial } \\
\text { press for the year }\end{array}$ \\
\hline MARKET VALUE & $(-)$ & $\begin{array}{l}\text { The beginning of year share price } \\
\text { multiplied by the number of ordinary } \\
\text { shares in issue in millions }\end{array}$ \\
\hline
\end{tabular}




\section{REFERENCES}

Acker, D., M. Stalker, and I. Tonks. 2002. "Daily closing inside spreads and trading volumes around earnings announcements." Journal of Business Finance \& Accounting 29:1149-1179.

Adams, R. B. and D. Ferreira. 2009. "Women in the boardroom and their impact on governance and performance.” Journal of Financial Economics 94:291-309.

Armstrong, C., K. Balakrishnan, and D. Cohen. 2012. "Corporate governance and the information environment: Evidence from state antitakeover laws." Journal of Accounting and Economics 53:185-204.

Bebchuk, L. and J. Fried. 2003. "Executive compensation as an agency problem." Journal of Economic Perspectives 17:71-92.

Belghitar, Y., E. Clark, and K. Kassimatis. 2011. "The prudential effect of strategic institutional ownership on stock performance." International Review of Financial Analysis 20:191-199.

Belghitar, Y. and J. Khan. 2011. Governance mechanisms, investment opportunity set and SMEs cash holdings. Small Business Economics 40:59-72.

Boubaker, S., H. Mansali, and H. Rjiba. 2014. "Large controlling shareholders and stock price synchronicity." Journal of Banking and Finance 40:80-96.

Brickley, J., J. Coles, and R. Terry. 1994. "Outside directors and the adoption of poison pills.” Journal of Financial Economics 35:371-390.

Byrd, J. W. and K. A. Hickman. 1992. "Do outside directors monitor managers?: Evidence from tender offer bids." Journal of Financial Economics 32:195-221.

Cai, C., K. Keasey, and H. Short. 2006. "Corporate governance and information efficiency in security markets.” European Financial Management 12:763-787.

Carpenter, M. A., D. C. Indro, S. R. Miller, and M. Richards. 2010. "CEO StockBased Pay, Home-Country Risk, and Foreign Firms' Capital Acquisition in the US Market." Corporate Governance: An International Review 18:496-510.

Carpenter, M. A., D. C. Indro, S. R. Miller, and M. Richards. 2010. "CEO stockbased pay, home-country risk, and foreign firms' capital acquisition in the U.S. market." Corporate Governance: An International Review 18:496-519.

Chahine, S. and I. Filatotchev. 2011. "The effects of corporate governance and audit and non-audit fees on IPO Value. The British Accounting Review 43: $155-172$.

Chen, E. T. and J. Nowland. 2010. "Optimal board monitoring in family-owned companies: Evidence from Asia." Corporate Governance: An International Review 18:3-17.

Chen, W. P., H. Chung, C. Lee, and W. L. Liao. 2007. "Corporate governance and equity liquidity: analysis of S\&P transparency and disclosure rankings." Corporate Governance: An International Review 15:644-660.

Chi, J. D. and D. S. Lee. 2010. "The conditional nature of the value of corporate governance." Journal of Banking \& Finance 34:350-361.

Cotter, J. F., A. Shivdasani, and M. Zenner. 1997. "Do independent directors enhance target shareholder wealth during tender offers?" Journal of Financial Economics 43:195-218. 
Degryse, H. and A. De Jong. 2006. "Investment and internal finance: Asymmetric information or managerial discretion?" International Journal of Industrial Organization 24:125-147.

Dermine, J. 2013. "Bank corporate governance, beyond the global banking." Financial Markets, Institutions \& Instruments 22:259-281.

Deshmukh, S. 2005. "The effect of asymmetric information on dividend policy." Quarterly Journal of Business \& Economics 44:107-127.

Diamond, D. 1985. “Optimal release of information by firms." Journal of Finance 40:1071-1094.

Diamond, W. D. and R. Verrecchia. 1991. "Disclosure, liquidity and the cost of capital." Journal of Finance 46:1325-1359.

Draper, P. and K. Paudyal. 2008. "Information asymmetry and Bidders' Gains." Journal of Business Finance \& Accounting 35:376-405.

Fama, E. and M. Jensen. 1983. "Separation of ownership and control." Journal of Law and Economics 88:288-307.

Florackis, C. and A. Ozkan. 2009. "The impact of managerial entrenchment on agency costs: An empirical Investigation using UK panel data." European $\mathrm{Fi}$ nancial Management 15:497-528.

Francis, B. B., I. Hasan, M. Koetter, and Q. Wu. 2012. "Do corporate boards matter during the current financial crisis?" Journal of Financial Research 35:521-552.

Gajewski, J. 1999. "Earnings announcements, asymmetric information, trades and quotes." European Financial Management 5:411-424.

George, T., G. Kaul, and M. Nimalendran. 1991. "Estimation of the bid-ask spread and its components: a new approach." Review of Financial Studies 4:623-656.

Gul, F., J. B. Kim, and A. Qiu. 2010. "Ownership concentration, foreign shareholding, audit quality, and stock price synchronicity: Evidence from China." Journal of Financial Economics 95:425-442.

Heckman, J. 1979. "Sample selection bias as a specification error." Econometrica 47:153-161.

Hefline, F. and K. Shaw. 2000. "Blockholder ownership and market liquidity." Journal of Financial and Quantitative Analysis 35:621-633.

Hillier, D. and P. McColgan. 2006. "An analysis of changes in board structure during corporate governance reforms." European Financial Management 12:575-607.

Huang, R. and H. Stoll. 1997. "The components of the bid-ask spread: a general approach." Review of Financial Studies 10:995-1034.

Jensen, M. and W. Meckling. 1976. "Theory of the firm: Managerial behaviours agency costs and ownership structure." Journal of Financial Economics 3:305-360.

Jiang, H., A. Habib, and B. Hu. 2011. "Ownership concentration, voluntary disclosures and information asymmetry in New Zealand." British Accounting Review 43:39-53.

Johnston, J. and J. Madura. 2009. "The pricing of Initial Public Offerings since the Sarbanes-Oxley act." Financial Review 44:291-310. 
Judge, G., W. Griffiths, R. Hill, H. Lutkepohl, and T. Lee. 1985. The theory and practise of econometrics (Wiley).

Kanagaretnam, K., G. Lobo, and D. Whalen. 2007. "Does good corporate governance reduce information asymmetry around quarterly earnings announcements?" Journal of Accounting and Public Policy 26:497-522.

Kang, S., P. Kumar, and H. Lee. 2006. "Agency and corporate investment: the role of executive compensation and corporate governance." Journal of Business 79:1127-1147.

Kisgen, D. J. and P. E. Strahan. 2010. "Do regulations based on credit ratings affect a firm's cost of capital?" Review of Financial Studies 23:4324-4347.

Leung, S. and B. Horwitz. 2010. "Corporate governance and firm value during a financial crisis." Review of Quantitative Finance \& Accounting 34:459-481.

Lin, C., Y. Ma, P. Malatesta, and Y. Xuan. 2011. "Ownership structure and the cost of corporate borrowing." Journal of Financial Economics 100:1-23.

Lin, J., G. Sanger, and G. Booth. 1995. "Trade size and components of the bid-ask spread." Review of Financial Studies 8:1153-1183.

Lin, W-C. and S.-C. Chang. 2012. "Corporate governance and the stock market reaction to new product announcements." Review of Quantitative Finance \& Accounting 39:273-291.

Madhavan, A., M. Richardson, and M. Roomans. 1997. "Why do security prices change? A transaction-level analysis of NYSE stocks." Review of Financial Studies 10:1035-1064.

Menyah, K. and K. Paudyal. 2000. "The components of bid-ask spreads on the London Stock Exchange." Journal of Banking and Finance 24:1767-1785.

Miller, R. M. 2002. “Can markets learn to avoid bubbles?” Journal of Psychology \& Financial Markets 3L 44-52.

O'Neill, M. and J. Swisher. 2003. "Institutional investors and information asymmetry: an event study of self-tender offers." Financial Review 38:197-211.

Opp, C. C., M. M. Opp, and M. Harris. 2013. "Rating agencies in the face of regulation." Journal of Financial Economics 108:46-61.

Pawlina, G. and L. Renneboog. 2005. "Is investment-cash flow sensitivity caused by agency costs or asymmetric information? Evidence from the UK." European Financial Management 11:483-513.

Perotti, E. and E. Ludwig von Thadden. 2003. Strategic transparency and informed trading: will capital market integration force convergence of corporate governance?, Journal of Financial and Quantitative Analysis 38:61-85.

Perry, T. and A. Shivdasani. 2005. "Do boards affect performance? Evidence from corporate restructuring." Journal of Business 78:1403-1432.

Schleifer, A. and R. Vishny. 1997. "A survey of corporate governance." Journal of Finance 52:737-783.

Switzer, L. N. and J. Wang. 2013. "Default risk estimation, bank credit risk, and corporate governance." Financial Markets, Institutions \& Instruments 22:91112. 
Van Ness, B., R. Van Ness, and R. Warr. 2001. "How well do adverse selection components measure adverse selection?" Financial Management 30:77-98.

Wang, J. 1993. "A model of inter-temporal asset prices under asymmetric information." Review of Economic Studies 60:249-282.

Weisbach, M. 1988. "Outside directors and CEO turnover." Journal of Financial Economics 20:431-460.

Wruck, K. 1993. "Stock-based incentives and investment decisions." Journal of Accounting \& Economics 16:373-380.

\section{NOTES ON CONTRIBUTORS/ACKNOWLEDGMENTS}

Ahmed Elbadry is a Lecturer of Finance and Investment in the Business Administration Department, Faculty of Commerce, Cairo University, Egypt. Currently, Ahmed is an Assistant Professor of Finance in the School of Business, Financial Sciences Department, King Faisal University, Saudi Arabia. He holds a B.Com in Business Administration and MSc in Finance from Cairo University, and a $\mathrm{PhD}$ in Finance from Surrey University, UK. He was an Academic Coordinator of the Business Administration Program in Cairo University and the Executive Manager of the Corporate Governance and Social Responsibility Unit in Cairo University. His research interests include Corporate Governance, Mergers and Acquisitions, Political Finance, Behavioural Finance and Risk Management.

Dimitrios Gounopoulos is a Reader (Associate Professor) in Accounting and Finance, University of Sussex. His research interests include Initial Public Offerings (IPOs); Gold - Precious Metals - Industrial Metals (Commodities); Political Connections; Education of CEOs; Seasoned Equity Offerings (SEOs); Corporate Governance; Executive Compensation; and Bond Issues. Since 2010, he has published in a wide range of well-known international finance academic journals (e.g., Journal of Financial Research, Journal of Banking and Finance, European Financial Management etc.) and top international journals in other disciplines (i.e. Annals of Tourism Research, Transportation Research Part E: Logistics and Transportation Review, Maritime Policy and Management, etc.). He is an independent consultant on IPOs providing counselling to multinational corporations. He delivers as well IPO courses in Universities and Financial Organizations. He has close collaboration with NYSE - Euronext Amsterdam and holds Visiting Appointments at the Universities of Birmingham, Glasgow, Nottingham and Southampton.

Frank Skinner is a Professor of Corporate Finance at Brunel University and a Visiting Professor of Finance at the University of Surrey Business School. After serving as Subject Group Leader for six years at the University of Surrey, he moved to Brunel where he manages the relationship between the LBIC, an associate college of Brunel University, and the Department of Economics and Finance. His research is mostly in the area of finance. He is broadly published in a wide variety of high quality finance journals such as The Journal of Banking and Finance, The Journal of Financial Research and the Financial Markets, Institutions 
and Instruments. Some recent examples of his work are in the area of Corporate Finance, (The choice among non-callable and callable bonds; Governance Quality and Information Asymmetry), Investments (Term Structure Information and Bond Investment Strategies), International Finance (Covered Interest Rate Parity in Emerging Markets), Financial Geography (Visibly in Trouble: Northern Rock, A Post-mortem on a Financial Crisis) and Financial Accounting (Voluntary vs. Mandatory Earnings Management in IPOs).

We are grateful to Lawrence Booth, Michael Firth, Chris Florackis, Praveen Kumar, Stergios Leventis, participants at European Financial Management (EFMA) 2012, Multinational Finance Conference (MFS) 2013, Financial Engineering and Banking Society and seminar participants at the University of Brunel, University of Middlesex and University of Surrey Conference on Banking, Finance, Money and Institutions for useful comments and suggestions. 